\title{
Studies of the Effect of Tenuazonic Acid on Plant Cells and Seedlings
}

\author{
Noriharu Umetsu, Takeharu Muramatsu, Hiroshi HondA* and Kinjiro TamarI \\ Department of Agricultural Chemistry, Faculty of Agriculture, \\ Tohoku University, Sendai, Japan \\ Received October 8, 1973
}

\begin{abstract}
The biological and biochemical studies of the effect of tenuazonic acid on plant cells and seedlings were carried out. Tenuazonic acid exhibited a conspicuous stunting effect on the seedling-growth of rice plant, mung bean, radish and turnip, and on the growth of suspension cultured cells of soybean and rice plants. Tenuazonic acid exhibited no effect on the $\mathrm{O}_{2}$-uptake and the activity of $\mathrm{SH}$-enzyme of the plant, but inhibited the incorporation of ${ }^{14} \mathrm{C}$-leucine into the protein fraction and that of ${ }^{14} \mathrm{C}$-adenine into nucleic acid fraction of suspension cultured soybean cells as well as these uptake into the cells. And then it has been proved that these incorporation-inhibitions were not merely due to the inhibition of ${ }^{14} \mathrm{C}$ leucine and ${ }^{14} \mathrm{C}$-adenine uptake into the cells but based on the intrinsic inhibition of protein and nucleic acid syntheses, respectively.
\end{abstract}

The symptom of blast disease suggests that the blast fungus (Piricularia oryzae cavara) produces some effective toxic substances. In 1954, Tamari and $\mathrm{Kaji}^{1}$ isolated piricularin and $a$-picolinic acid from the culture broth of blast fungus and demonstrated their presence in the stunted rice plants affected with blast disease. They also isolated coumarin ${ }^{2,3}$ from severely blast-diseased rice plants and revealed that these three toxins might play an important role in disease development.

The authors ${ }^{4}$ and Iwasaki et al. ${ }^{5}$ have recently isolated tenuazonic acid (T.A.) from the culture broth of blast fungus. The authors ${ }^{6}$ ) have also isolated this acid from blast-diseased rice plants and demonstrated that this acid was one of the principal vivotoxins of blast disease. Application of T.A. to a small mechanically wounded area of rice leaf, made with punchlike instrument, caused a necrotic spot similar to that of blast disease. ${ }^{4)}$ On the other hand, Mikami et al. ${ }^{7 /}$ isolated T.A. as a vivotoxin of tobacco brown-spot disease.

T.A. was first isolated as an antitumor agent from the culture broth of Alternaria tenuis by Rosett et al. ${ }^{8)}$ Shigeura and Gordon" report-

* Present address: Meito Sangyo Co., Ltd., Hachioji, Japan. ed that T.A. inhibited the incorporation of amino acid into protein with Ehrlich ascites tumor, rat liver and then with rat (in vivo). On the other hand, very meager information on the plant-growth inhibition mechanism of T.A. is available.

From this view point, this paper deals with the biological and biochemical studies of the effect of T.A. on plant cells and seedlings.

\section{MATERIALS AND METHODS}

Plant material and growth-inhibition test. Rice plant, mung bean (Phaseorus aureus), radish and turnip (Sazanami) were used for the seedling-growth inhibition test. The seeds were sterilized with $0.1 \% \mathrm{HgCl}_{2}$ for $10 \mathrm{~min}$, washed with water and then placed on wet filter paper, being allowed to germinate. The seedlings of uniform size were then selected and transferred onto wet absorbent cotton in a glass dish $(3.0 \mathrm{~cm}$ in diameter, $2.0 \mathrm{~cm}$ in depth) containing $4.0 \sim 8.0 \mathrm{ml}$ of test solution. The glass dishes were then placed in a growth cabinet under the dark for $3 \sim 7$ days.

Radioactive chemicals and regent. The labelled compounds were obtained from Daiichi Pure Chemicals Co., Ltd., Tokyo, Japan.

T.A. was synthesized from $\mathrm{L}$-isoleucine and diketene according to the method of Harris et al. ${ }^{10)}$ The synthesized T.A. $\left([a]_{\mathrm{D}}^{20}-105^{\circ}, c=2.0\right.$ in methanol) is mainly composed of L-tenuazonic acid. ${ }^{11}$ In order to prevent 
from a change of optical rotation, T.A. was preserved as a cupric salt.

Suspension culture of isolated plant cells. Cells from the root tissue of soybean and rice plant were provided by Dr. K. Ojima, Tohoku University. The suspension culture of soybean cell was carried out using the method of Gamborg et al. ${ }^{12}$ The cells were cultured under sterile conditions in a $250 \mathrm{ml}$ Erlenmyer flask containing $50 \mathrm{ml}$ of $\mathrm{B}_{5}$ medium ${ }^{12}$ (consisted of sucrose, $m$-inositol, 2,4-D, vitamines and inorganic salts) with or without T.A., with gentle shaking for $2 \sim 12$ days at $27^{\circ} \mathrm{C}$ under continuous light (300 400 lux) from white fluorescent lamps. The suspension culture of rice plant cell was carried out similarly in a $250 \mathrm{ml}$ Erlenmyer flask containing $50 \mathrm{ml}$ of the $\mathrm{R}_{2}$ medium ${ }^{131}$ (consisted of sucrose, 2,4-D, vitamine $B$ and inorganic salts) with or without T.A.

Measurement of $\mathrm{O}_{2}$-uptake of plant materials. Rice seedlings of uniform size (age: 5 days, length: $3.0 \sim 4.0$ $\mathrm{cm}$ ) were vacuum-immersed in T.A. solution of each concentration for $5 \sim 24 \mathrm{hr}$. Control sample was similarly vacuum-immersed in distilled water. After vacuum-immersion, each of the samples was transferred into the modified Warburg vessels and the $\mathrm{O}_{2}$-uptake during $20 \mathrm{~min}$ was measured.

Suspension cultured soybean-cells, $500 \mathrm{mg}$ cells in $3.0 \mathrm{ml}$ of $\mathbf{B}_{5}$ medium containing T.A. of each concentration, were transferred into Warburg vessels, containing $0.2 \mathrm{ml}$ of $20 \% \mathrm{KOH}$ in the center well, and after pre-incubation period, the $\mathrm{O}_{2}$-uptake of the cells during 20 min was measured.

Incorporation test of radioactive precursors into protein and nucleic acid fractions of suspension cultured soybean cells. Suspension cultured soybean cells were incubated at $27^{\circ} \mathrm{C}$ under shaking in a $250 \mathrm{ml}$ Erlenmyer flask with $60 \mathrm{ml}$ of the $\mathrm{B}_{5}$ medium containing ${ }^{14} \mathrm{C}$ leucine or ${ }^{14} \mathrm{C}$-adenine and each $10 \mathrm{ml}$ aliquot $(0.3 \sim$ $0.5 \mathrm{~g}$ of cells in fresh weight) was pipetted with predetermined intervals into a test tube containing $10 \mathrm{ml}$ of chilled $\mathrm{B}_{5}$ medium. The test tube was allowed to stand in an ice bath and the resulted precipitate (cells) was collected on Miracloth, followed by washing with the medium. The filtrate was filled up to $25 \mathrm{ml}$ and the radioactivity was measured.

The procedure to determine the incorporation of ${ }^{14} \mathrm{C}$ leucine into the protein fraction is as follows: The collected cells were homogenized in $1 \mathrm{ml}$ of $0.02 \mathrm{M}$ Tris- $\mathrm{HCl}$ buffer $\left(\mathrm{pH} \mathrm{7.6)}\right.$ ) for 3 min at $0^{\circ} \mathrm{C}$. The homogenate was transferred into a centrifuge tube, being added with $2 \mathrm{ml}$ of the chilled buffer solution, and centrifuged at $1000 \times g$ for $10 \mathrm{~min}$. This washing procedure was repeated three times. The supernatant and washings were combined and cold trichloroacetic acid (TCA) was added to bring the final concentration of $5 \%$ and allowed to stand overnight. The resulted precipitate was separated by centrifugation $(1100 \times g, 10 \mathrm{~min})$ and was suspended again in $2 \mathrm{ml}$ of cold $5 \%$ TCA, followed by the same procedures being repeated three times. The supernatant and washings were combined and designated as the "TCA soluble fraction." The precipitate was dissolved in $2 \mathrm{~N} \mathrm{NH}_{4} \mathrm{OH}$ and designated as the "protein fraction." Protein contents in the protein fraction was determined by Lowry's method. ${ }^{14}$

The extraction of nucleic acid from the cells was run after the modified method of Schmidt-Thannhauser. ${ }^{15}$ ) The procedure to determine the incorporation of ${ }^{14} \mathrm{C}$ adenine into the nucleic acid fraction is as follows: The cells were ground in a mortar containing $1 \mathrm{ml}$ of $0.02 \mathrm{M}$ Tris- $\mathrm{HCl}$ buffer ( $\mathrm{pH} \mathrm{7.6)}$ for $3 \mathrm{~min}$ at $0^{\circ} \mathrm{C}$ and transfered into centrifuge tube, washing with another $1 \mathrm{ml}$ of the buffer solution. Two milliliters of cold $5 \%$ perchloric acid (PCA) was added to bring the final concentration to $2.5 \%$, followed by centrifugation at $8000 \times g$ for $15 \mathrm{~min}$. The precipitate thus obtained was suspended in $2 \mathrm{ml}$ of $2.5 \%$ PCA and centrifuged at $8000 \times g$ for $15 \mathrm{~min}$, being repeated once again. The supernatant and washings were combined and designated as the "PCA soluble fraction." The precipitate was suspended in $2 \mathrm{ml}$ of $5 \% \mathrm{PCA}$ and hydrolyzed at $95^{\circ} \mathrm{C}$ for $15 \mathrm{~min}$, followed by centrifugation at $8000 \times g$ for $15 \mathrm{~min}$. The precipitate was then washed twice with $2 \mathrm{ml}$ of $5 \%$ PCA by centrifugation at $8000 \times g$ for $15 \mathrm{~min}$. The supernatant and washings were combined and designated as the "nucleic acid fraction." Nucleic acid contents in the nucleic acid fraction was determined by the absorbance at $260 \mathrm{~nm}$.

Measurement of radioactivity. Each $1 \mathrm{ml}$ aliquot of the above mentioned TCA soluble fraction, the PCA soluble fraction and the nucleic acid fraction was dissloved in $6 \mathrm{ml}$ of dioxan scintillator fluid. And then, $1 \mathrm{ml}$ aliquot of the protein fraction was dissolved in $0.2 \mathrm{ml}$ of hyamine plus $6 \mathrm{ml}$ dioxane scintillator fluid.

In the case of cells, about $10 \mathrm{mg}$ of each sample was placed in the counting vials with $6 \mathrm{ml}$ of toluene scintillator fluid. The radioactivities of these specimens were counted with a liquid scintillation counter.

\section{RESULTS}

\section{Growth inhibiting effect of $T$.A. on seedlings}

T.A. inhibited the growth of rice seedlings perfectly at $2.5 \times 10^{-4} \mathrm{M}$ and by $50 \sim 100 \%$ at $1.25 \times 10^{-4}$, and then inhibited that of mung bean seedlings $\left(70 \%\right.$ at $\left.5.0 \times 10^{-4} \mathrm{M}\right)$, that of radish seedlings $\left(90 \%\right.$ at $1.0 \times 10^{-3} \mathrm{M}$ and $50 \%$ at $\left.5.0 \times 10^{-4} \mathrm{M}\right)$ and that of turnip seedlings $\left(90 \sim 100 \%\right.$ at $5.0 \times 10^{-4} \mathrm{M}$ and $50 \%$ at $1.25 \times$ $\left.10^{-4} \mathrm{M}\right)$. Root growth-inhibition of all seed- 

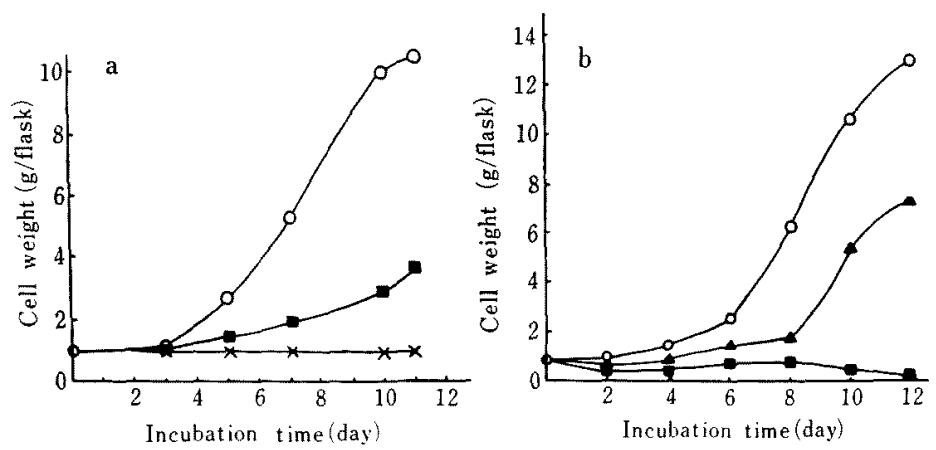

FIG. 1. Effect of T.A. on the Growth of Suspension Cultured Cells of Rice Plant and Soybean.

a, rice plant; $b$, soybean.

Each $5 \mathrm{ml}$ aliquot of seed cultures $(6 \sim 8$ days age) was added into $250 \mathrm{ml}$ Erlenmyer flask containing $50 \mathrm{ml}$ of $\mathrm{R}_{2}$ (for rice plant) and $\mathrm{B}_{5}$ media (for soybean) with or without T.A. and incubated at $27^{\circ} \mathrm{C}$. Cell growth is expressed as fresh weight per flask. $O-O$, control (incubated in $R_{2}$ or $\mathbf{B}_{5}$ media); $\triangle-\Delta$, treated with $1.25 \times 10^{-4}$ M of T.A.; treated with $1.0 \times 10^{-3} \mathrm{M}$ of T.A.

lings tested was observed to be more severe.

It is noteworthy that the growth-inhibition of rice seedlings by T.A. was conspicuous among those of the seedlings tested.

Effect of T.A. on the growth of suspension cultured cells of rice plant and soybean

The growth of suspension cultured cells of rice plant and soybean was inhibited by T.A. As shown in Fig. 1-a, the growth of rice plant cells was inhibited by T.A. about $60 \sim 70 \%$ at $2.5 \times 10^{-4} \mathrm{M}$ and almost perfectly at $1.0 \times$ $10^{-3} \mathrm{M}$. The growth inhibition of soybean cell was more severe (Fig. 1-b), 40 50\% at $1.25 \times 10^{-4} \mathrm{M}$ and almost perfectly at $2.5 \times$ $10^{-4} \mathrm{M}$.

Effect of T.A. on $\mathrm{O}_{2}$-uptake of plant materials

The effect of T.A. on the $\mathrm{O}_{2}$-uptake of rice

TABle 1. EFFEct OF T.A. ON THE $\mathrm{O}_{2}$-UPtake of Rice SeEdLings

\begin{tabular}{cccc}
\hline \multirow{2}{*}{$\begin{array}{c}\text { Concentration of } \\
\text { T.A. (M) }\end{array}$} & \multicolumn{3}{c}{$\begin{array}{c}\text { O} \text {-uptake after each vacuum- } \\
\text { immersion period }\end{array}$} \\
\cline { 2 - 4 } & $5 \mathrm{hr}$ & $10 \mathrm{hr}$ & $24 \mathrm{hr}$ \\
\hline 0 & $89.6^{a)}$ & $64.1^{a}$ & $56.2^{a}$ \\
$2.5 \times 10^{-4}$ & 81.8 & 68.8 & 50.6 \\
$5.0 \times 10^{-4}$ & 70.4 & 56.3 & 46.2 \\
$1.0 \times 10^{-3}$ & 72.5 & 57.7 & 53.0 \\
\hline
\end{tabular}

a) $\mu 1 / \mathrm{vessel} / 20 \mathrm{~min}$. seedlings and suspension cultured soybeancells has been investigated. As shown in Table I, T.A. in a concentration range of $2.5 \times 10^{-4} \sim$ $1.0 \times 10^{-3} \mathrm{M}$ revealed no significant effects on the $\mathrm{O}_{2}$-uptake of rice seedlings in $5 \sim 24 \mathrm{hr}$ period. And then, the $\mathrm{O}_{3}$-uptake was scarcely inhibited under such a high T.A. concentration of $1.0 \times 10^{-3} \mathrm{M}$, which inhibited the rice-seedling-growth perfectly.

The same is also the case with the experimental results obtained with suspension cultured soybean-cells.

In conclusion, T.A. manifested no effects on the $\mathrm{O}_{2}$-uptakes of rice seedlings and suspension cultured soybean-cells.

Effect of sulfhydryl compounds on the inhibitory action of T.A. on seedling-growth

The effect of cysteine and thioglycolate on the growth inhibition of test seedlings induced by T.A. $\left(1.25 \times 10^{-4} \mathrm{M}\right)$ was investigated. Test rice grains (Fujiminori) were grown with or without addition of T.A. $\left(1.25 \times 10^{-4} \mathrm{M}\right)$ at $27^{\circ} \mathrm{C}$ for 6 days on wet absorbent cotton in a glass dish containing cystein or thioglycolate (each $5.0 \times 10^{-4} \mathrm{M}$ ). The experimental results demonstrated that the inhibition of rootelongation of rice seedlings by T.A. was hardly reversed by the simultaneous addition of the cysteine or thioglycolate. From this observation, it may be concluded that T.A. has no 

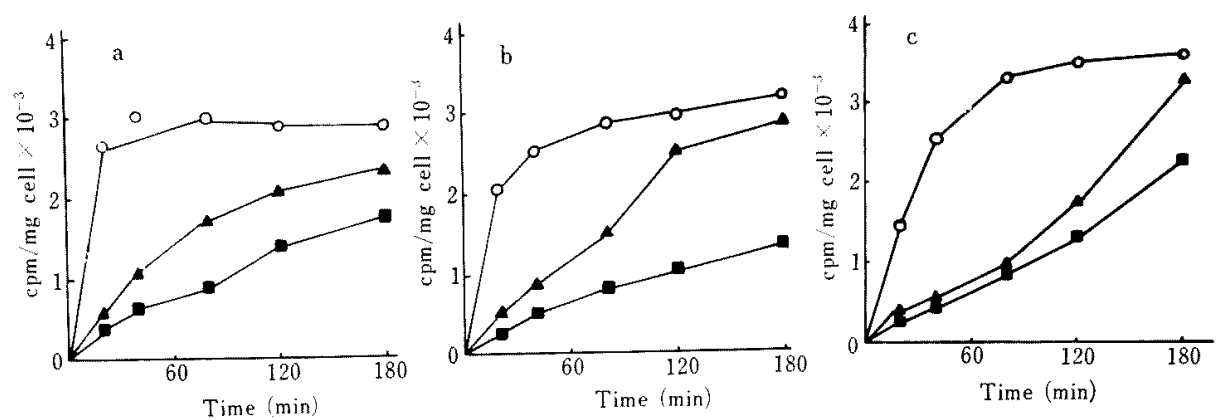

FIG. 2. Time Course of the Effect of T.A. on the Uptake of Amino Acid and Purine Base into Suspension Cultured Cells.

a, uptake of leucine; $b$, uptake of valine; $c$, uptake of adenine.

Soybean cells $(3,0 \mathrm{~g})$ were pre-incubated for $1 \mathrm{hr}$ in a $250 \mathrm{ml}$ Erlenmyer flask containing $60 \mathrm{ml}$ of $B_{5}$ medium with or without T.A., after which ${ }^{14} \mathrm{C}$-labelled leucine or varine or adenine (each $0.5 \mu$ Ci) was added respectively to bring the final concentration of $5.0 \times 10^{-6} \mathrm{M}$ and incubated for $20 \sim$ $180 \mathrm{~min}$. At predetermined intervals, $10 \mathrm{ml}$ aliquots of the culture broth were pipetted and radioactivities absorbed into the cells were measured. $\mathrm{O}-\mathrm{O}$, control; $\boldsymbol{\Delta}-\boldsymbol{\Delta}$, treated with $1.25 \times$ $10^{-4} \mathrm{M}$ of T.A.; $-\mathbf{D}$, treated with $2.5 \times 10^{-4} \mathrm{M}$ of T.A.

effect on sulf hydryl radicals.

Time course of the effect of T.A. on the uptake of amino acid and purine base into suspension cultured cells

Our preliminary study has demonstrated that an uptake of ${ }^{14} \mathrm{C}$-leucine into suspension cultured soybean cells (decrease in radioactivity in the medium), as well as the incorporation of it into the protein fraction, was remarkably inhibited by T.A. Therefore, the effect of T.A. on the uptake of ${ }^{14} \mathrm{C}$-labelled leucine, valine and adenine into the cells has been studied in detail.

The effect of T.A. on the time course of the uptake of ${ }^{14} \mathrm{C}$-labelled leucine, valine and adenine into the cells was shown in Fig. 2-a, b, $c$, respectively. T.A. inhibited the uptake of all labelled compounds into the cells in $20 \sim$ $180 \mathrm{~min}$ incubation period at concentrations of $1.25 \times 10^{-4} \mathrm{M}$ and $2.5 \times 10^{-4} \mathrm{M}$. This finding was also confirmed by simultaneous measurement of the decrease in radioactivity in the medium. It is noteworthy that T.A. remarkably inhibited the uptake of all labelled compounds into the cells in the early stage of incubation (at $20 \sim 40 \mathrm{~min}$ ), but this inhibition gradually decreased. This phenomenon may be elucidated that most of the radioactivity in the medium was absorbed into control cells during the early incubation period, whereas the uptake of that into the cells treated with T.A. was delayed.

Time course of the effect of T.A. on the incorporation of ${ }^{14} \mathrm{C}$-leucine into the protein fraction

In order to investigate the effect of T.A. on protein synthesis, the effects of T.A. on the incorporation of ${ }^{14} \mathrm{C}$-leucine into the protein fraction and the TCA soluble fraction were examined. ${ }^{14} \mathrm{C}$-Leucine-incorporation into these fractions of the cells was affected by delicate fluctuation of the experimental conditions, that is, concentration of leucine added in the medium as a carrier, cultural temperature and especially cell age. Remarkable difference in the uptake velocity of ${ }^{14} \mathrm{C}$-leucine between the cells of early exponential stage and those of late exponential stage was observed in our preliminary experiment. Therefore, the experiment was carried out with the cells of different ages.

\section{a) Experiment-I}

The experiment was run with the cells of late exponential stage $(8 \sim 10$ days age $)$. The decrease in radioactivity in the medium, which represents an uptake of ${ }^{14} \mathrm{C}$-leucine into the cells (Fig. 3-a), and its incorporation into the protein and TCA soluble fractions (Fig. 3- 

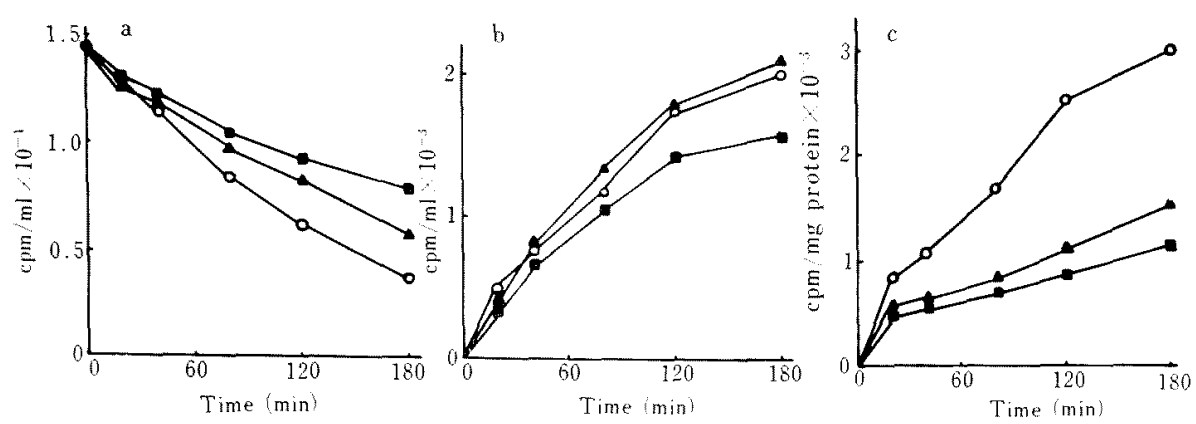

F1G. 3. Time Course of the Effect of T.A. on the ${ }^{14} \mathrm{C}$-Leucine-uptake into the Cells and its Incorporation into the TCA Soluble and Protein Fractions Using the Cells in Late Exponential Stage (Experiment I).

a, decrease in ${ }^{14} \mathrm{C}$-leucine in the medium which represents an uptake of ${ }^{14} \mathrm{C}$-leucine into the cells; $b$, radioactivity of TCA soluble fraction; $c$, incorporation of ${ }^{14} \mathrm{C}$-leucine into the protein fraction.

Soybean cells $(2.0 \mathrm{~g})$ in the late exponential stage were pre-incubated for $1 \mathrm{hr}$ in a $250 \mathrm{ml}$ Erlenmyer flask containing $60 \mathrm{ml} \mathrm{B}$ medium with or without T.A., after which ${ }^{14} \mathrm{C}$-leucine $(0.5$ " $\mathrm{Ci}$ ) was added to bring the final concentration of $5.0 \times 10^{-6} \mathrm{M}$ and incubated for $20 \sim 180 \mathrm{~min}$. At predetermined interval, $10 \mathrm{ml}$ aliquots of the culture broth were removed and with each of them the radioactivity in the medium and the incorporation of ${ }^{14} \mathrm{C}$-leucine into the TCA soluble and protein fractions were measured. $O-O$, control; $\mathbf{\Delta}-\mathbf{\Lambda}$, treated with $7.5 \times 10^{-5} \mathrm{M}$ of T.A.; - - , treated with $1.25 \times 10^{-4} \mathrm{M}$ of T.A. Each TCA soluble fraction was filled up to $20 \mathrm{ml}$ and radioactivity was indicated for one milliliter.

$b, c)$ proceeded lineary with incubation period during $20 \sim 180 \mathrm{~min}$. T.A. of $7.5 \times 10^{-5} \mathrm{M}$ and $1.25 \times 10^{-4} \mathrm{M}$, inhibited the uptake of ${ }^{14} \mathrm{C}$-leucine by about $20 \%$ and $35 \%$, respectively and then inhibited its incorporation into the protein fraction about $50 \%$ and $70 \%$, respectively. The experimental result that T.A. inhibited the incorporation of leucine into the protein fraction more severe than the uptake of leucine into the cell reflects that T.A. inhibited the biogenesis of protein in soybean.
Table II, which shows the distribution of radioactivity after $180 \mathrm{~min}$ incubation, also supported this conception. The ratio of radioactivities incorporated into the protein to that absorbed in the cells with or without the effect of T.A. was $12.7 \%$ (control), $8.8 \%$ $\left(7.5 \times 10^{-5} \mathrm{M}\right.$ of T.A.) and $6.5 \%\left(1.25 \times 10^{-4} \mathrm{M}\right.$ of T.A.), respectively. In conclusion, $7.5 \times$ $10^{-5} \mathrm{M}$ and $1.25 \times 10^{-4} \mathrm{M}$ of T.A. inhibited the incorporation into protein of the leucine, absorbed into the cell, by about $30 \%$ and

Table II. EfFect of T.A. ON the Incorporation of ${ }^{14}$ C-Levcine into EACH FraCtion afTER 180 MIN INCUBATION IN EXPERIMENT I

\begin{tabular}{|c|c|c|c|}
\hline & \multicolumn{3}{|c|}{$\begin{array}{l}\text { Radioactivity } \\
(\mathrm{cpm} / 10 \mathrm{ml} \text { of culture broth) }\end{array}$} \\
\hline & Control & $\begin{array}{l}7.510^{-5} \mathrm{M} \\
\text { of T.A. }\end{array}$ & $\begin{array}{l}1.2510^{-4} \mathrm{M} \\
\text { of T.A. }\end{array}$ \\
\hline Activity supplied & $145,350 \mathrm{cpm}$ & $145,350 \mathrm{cpm}$ & $145,350 \mathrm{cpm}$ \\
\hline Activity recovered in & & & \\
\hline (I) Medium at end of incubation & 36,075 & 60,325 & 79,075 \\
\hline (II) TCA soluble fraction & 64,500 & 67,540 & 49,660 \\
\hline (III) Protein fraction & 13,930 & 7,520 & 4,340 \\
\hline Uptake & 109,275 & 85,025 & 66,275 \\
\hline $\begin{array}{l}\text { Activity in protein fraction as } \\
\text { percentage of uptake }\end{array}$ & $12.7 \%$ & $8.8 \%$ & $6.5 \%$ \\
\hline
\end{tabular}



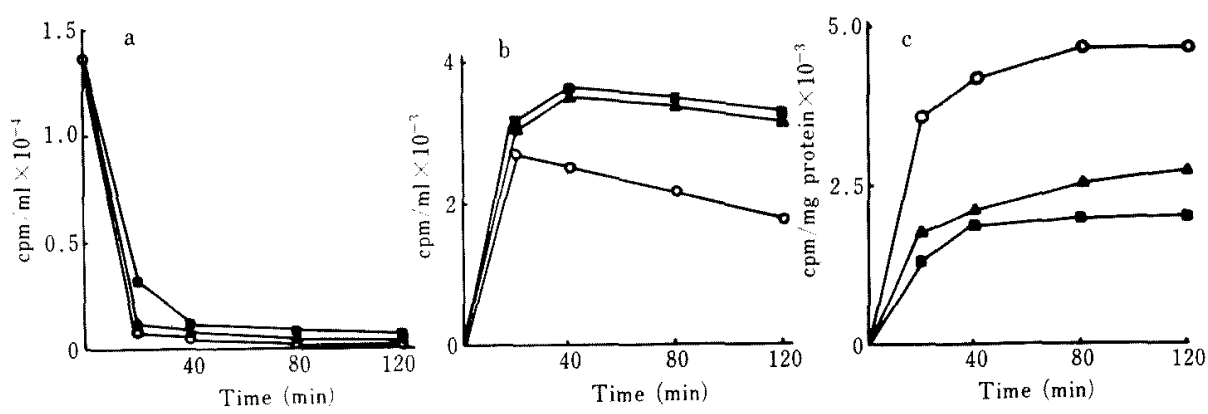

Fig. 4. Time Course of the Effect of T.A. on the ${ }^{14} \mathrm{C}$-Leucine-uptake into the Cells and its Incorporation into the TCA Soluble and Protein Fractions Using the Cells in Early Exponential Stage (Experiment II).

$a$, decrease in ${ }^{14} \mathrm{C}$-leucine in the medium; $b$, radioactivity of TCA soluble fraction; $c$, incorporation of ${ }^{14} \mathrm{C}$-leucine into the protein fraction.

The experiment was carried out using the soybean cells $(3.0 \mathrm{~g})$ in the early exponential stage under the same condition as in Fig. 3. $\bigcirc-O$, control; $\mathbf{A}-\mathbf{A}$, treated with $7.5 \times 10^{-5} \mathrm{M}$ of T.A.; a- - , treated with $1.25 \times 10^{-4} \mathrm{M}$ of T.A.

$50 \%$, respectively.

\section{b) Experiment-II}

The experiment was run with the cells of early exponential stage ( $4 \sim 5$ days age). The radioactivity in the medium almost disappeared during $20 \sim 40 \mathrm{~min}$ incubation period with or without T.A. and uptake-inhibition of ${ }^{14} \mathrm{C}$ leucine by T.A. into the cells was not observed apparently, as shown in Fig. 4-a. On the other hand, the incorporation of ${ }^{14} \mathrm{C}$-leucine into protein fraction was inhibited with $7.5 \times 10^{-5} \mathrm{M}$ and $1.25 \times 10^{-4} \mathrm{M}$ of T.A. about $30 \%$ and $45 \%$, respectively as shown in Fig. 4-c. This finding is also concordant with Fig. 4-b, which demonstrates the fluctuation of the radioactivity in the TCA soluble fraction. T.A. of $7.5 \times 10^{-5} \mathrm{M}$ and $1.25 \times 10^{-4} \mathrm{M}$ largely increased the radioactivity in the TCA soluble fraction during $40 \sim 120 \mathrm{~min}$ incubation by incorporationinhibition of leucine into protein. In this experiment, the inhibition ratio of leucineincorporation into the protein fraction means that of the intrinsic leucine-incorporation into the protein fraction.

As shown in Table III, the ratio of radioactivity incorporated into the protein fraction in $120 \mathrm{~min}$ incubation to that absorbed into the cells was $25.6 \%$ (control), $17.7 \%$ (with $7.5 \times 10^{-5} \mathrm{M}$ of T.A.) and $14.2 \%$ (with $1.25 \times$ $10^{-4} \mathrm{M}$ of T.A.), respectively. This means that T.A. of these concentrations inhibited the

TABle III. EFfect OF T.A. ON THE InCORPoration OF ${ }^{14}$ C-LeUCINE INTO

EACH Fraction after 120 Min InCUbation In ExPERIMENT-II

\begin{tabular}{|c|c|c|c|}
\hline & \multicolumn{3}{|c|}{$\begin{array}{c}\text { Radioactivity } \\
(\mathrm{cpm} / 10 \mathrm{ml} \text { of culture broth) }\end{array}$} \\
\hline & Control & $\begin{array}{l}7.5 \times 10^{-5} \mathrm{M} \\
\text { of T.A. }\end{array}$ & $\begin{array}{l}1.25 \times 10^{-4} \mathrm{M} \\
\text { of T.A. }\end{array}$ \\
\hline Activity supplied & $136,550 \mathrm{cpm}$ & $136,550 \mathrm{cpm}$ & $136,550 \mathrm{cpm}$ \\
\hline Activity recovered in & & & \\
\hline (I) Medium at end of incubation & 2,200 & 3,625 & 6,075 \\
\hline (II) TCA soluble fraction & 55,420 & 99,900 & 102,040 \\
\hline (III) Protein fraction & 34,390 & 23,560 & 18,560 \\
\hline Uptake & 134,350 & 132,925 & 130,475 \\
\hline $\begin{array}{l}\text { Activity in protein fraction as } \\
\text { percentage of uptake }\end{array}$ & $25.6 \%$ & $17.7 \%$ & $14.2 \%$ \\
\hline
\end{tabular}



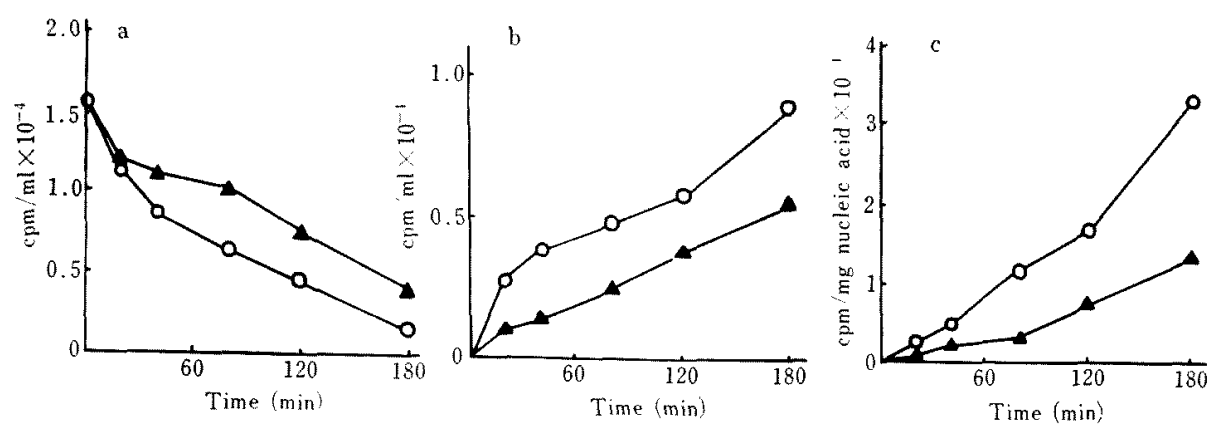

FIG. 5. Time Course of the Effect of T.A. on the ${ }^{14} \mathrm{C}$-Adenine-uptake into the Cells and its Incorporation into the PCA soluble and Nucleic Acid Fractions.

a, decrease in ${ }^{14} \mathrm{C}$-adenine in the medium which represents an uptake of ${ }^{14} \mathrm{C}$-adenine into the cells; $\mathrm{b}$, radioactivity of PCA soluble fraction; $\mathrm{c}$, incorporation of ${ }^{14} \mathrm{C}$-adenine into the nucleic acid fraction.

Soybean cells $(3.0 \mathrm{~g})$ in exponential stage were pre-incubated for $1 \mathrm{hr}$ in a $250 \mathrm{ml}$ Erlenmyer flask containing $60 \mathrm{ml}$ of $\mathrm{B}_{5}$ medium with or without T.A., after which ${ }^{14} \mathrm{C}$-adenine $(0.5 \mu \mathrm{Ci})$ was added to bring the final concentration of $5 \times 10^{-6} \mathrm{M}$ and incubated for $20 \sim 180 \mathrm{~min}$. At predetermined interval, $10 \mathrm{ml}$ of aliquots of the culture broth were removed and with each of them the radioactivity in the medium and the incorporation of ${ }^{14} \mathrm{C}$-adenine into the PCA soluble and nucleic acid fractions were measured. $O-O$, control; $\mathbf{\Lambda}-\mathbf{\Lambda}$, treated with $7.5 \times 10^{-5} \mathrm{M}$ of T.A. Each PCA soluble fraction was filled up to $8 \mathrm{ml}$ and the radioactivity was indicated for one milliliter.

intrinsic leucine-incorporation into the protein fraction by about $30 \%$ and $45 \%$, respectively. These inhibition ratio was in good agreement with those obtained by Experiment-I.

Time course of the effect of T.A. on the incorporation of ${ }^{14} \mathrm{C}$-adenine into the nucleic acid fraction

Our experimental results demonstrated that T.A. inhibited the ${ }^{14} \mathrm{C}$-leucine incorporation into protein fraction of suspension cultured soybean cells. However, there is a possibility that T.A. may inhibit protein synthesis indire- ctly by interfering with nucleic acid synthesis. So the investigation of the effect of T.A. on the incorporation of ${ }^{14} \mathrm{C}$-adenine into the nucleic acid fraction has been carried out using suspension cultured soybean cells of exponential stage (7 days).

The decrease in radioactivity in the medium, which represents an uptake of ${ }^{14} \mathrm{C}$-adenine into the cells (Fig. 5-a), and the incorporation of ${ }^{14} \mathrm{C}$-adenine into the nucleic acid fraction (Fig. 5-c) and that into the PCA soluble fraction (Fig. 5-b) proceeded lineary with incubation period during $20 \sim 180 \mathrm{~min}$. T.A. of $7.5 \times$

TABLE IV. EFFECT OF T.A. ON THE INCORPORATION OF ${ }^{14} \mathrm{C}$-ADENINE INTO

EACH Fraction AFTER 120 MIN INCUBATION

\begin{tabular}{|c|c|c|}
\hline & \multicolumn{2}{|c|}{$\begin{array}{c}\text { Radioactivity } \\
(\mathrm{cpm} / 10 \mathrm{mil} \text { of culture broth) }\end{array}$} \\
\hline & Control & $7.5 \times 10^{-5} \mathrm{M}$ of T.A. \\
\hline Activity supplied & $156,486 \mathrm{cpm}$ & $156,486 \mathrm{cpm}$ \\
\hline \multicolumn{3}{|l|}{ Activity recovered in } \\
\hline (I) Medium at end of incubation & 46,134 & 77,792 \\
\hline (II) PCA soluble fraction & 69,480 & 47,295 \\
\hline (III) Nucleic acid fraction & 7,550 & 3,850 \\
\hline Uptake & 110,352 & 78,694 \\
\hline $\begin{array}{l}\text { Activity in nucleic acid fraction } \\
\text { as percentage of uptake }\end{array}$ & $6.48 \%$ & $4.89 \%$ \\
\hline
\end{tabular}


$10^{-5} \mathrm{M}$ inhibited the uptake of ${ }^{14} \mathrm{C}$-adenine by about $30 \sim 40 \%$ and the incorporation of it into the nucleic acid fraction by about $50 \sim 80 \%$. The experimental result that T.A. inhibited the incorporation of adenine into the nucleic acid fraction more severe than the uptake of adenine into the cell, reflects that T.A. also inhibited the biogenesis of nucleic acid as well as protein by some way.

As shown in Table IV, the ratio of radioactivity incorporated into the nucleic acid fraction in $120 \mathrm{~min}$ incubation to that transported into the cells was $6.8 \%$ (control) and $4.89 \%$ (with $7.5 \times 10^{-5} \mathrm{M}$ of T.A.), respectively. This means that T.A. inhibited the intrinsic adenine-incorporation into the nucleic acid fraction by about $30 \%$.

\section{DISCUSSION}

T.A. exhibited a marked stunting effect on the seedling-growth of rice plant, mung bean, radish and turnip and on the growth of suspension cultured cells of soybean and rice plants. It is noteworthy that the growthinhibition of rice seedling by T.A. was conspicuous among those of the seedlings tested.

Shigeura and Gordon ${ }^{9}$ have reported that T.A. inhibited the protein synthesis of rat and in vitro of Ehrlich ascites tumor and rat liver cells. And then, several reports ${ }^{16,17}$ ) have been presented which dealt with the effect of T.A. on the protein synthesis of yeast or animal cells. But, on the other hand, very meager information on the plant-growth inhibition mechanism is available. From this view point, the effect of T.A. on the respiration, the activity of SH-enzyme, protein synthesis and nucleic acid synthesis of plants has been studied.

Our experimental results demonstrated that T.A. exhibited no effect on the $\mathrm{O}_{2}$-uptake and the activity of SH-enzyme of plants, but inhibited the incorporation of ${ }^{14} \mathrm{C}$-leucine into the protein fraction as well as its uptake into the cells. And then it was also proved that the inhibition of ${ }^{14} \mathrm{C}$-leucine incorporation into protein fraction was not merely due to that of ${ }^{14} \mathrm{C}$-leucine uptake into the cell but based on the intrinsic inhibition of protein synthesis.

However, there is a possibility that T.A. may inhibit protein synthesis indirectly by interfering with nucleic acid synthesis. Contrary, there is also a possibility that the inhibition of protein synthesis secondarily results a inhibition of nucleic acid synthesis. The experimental results demonstrated that T.A. also inhibited the incorporation of ${ }^{14} \mathrm{C}$-adenine into the nucleic acid as well as its uptake into the cell, and then the inhibition of ${ }^{14} \mathrm{C}$-adenine incorporation into nucleic acid fraction was not merely due to that of ${ }^{14} \mathrm{C}$-adenine uptake into the cell but based on the intrinsic inhibition of nucleic acid biogenesis. The other experimental result which will be presented in another paper in detail demonstrated that more than $90 \%$ of the incorporated ${ }^{14} \mathrm{C}$-adenine into total nucleic acid was into RNA fraction.

As the inhibition ratio of nucleic acid synthesis was almost the same as that of protein synthesis, whether or not protein synthesis is inhibited directly or indirectly by interfering with nucleic acid synthesis, remained unknown. These problem will be elucidated in future by cell-free studies on protein and nucleic acid syntheses.

Rees and Bryant ${ }^{18}$ reported that cycloheximide inhibited the protein synthesis of carrot tissue and also the uptake of leucine into the cells. T.A. remarkably inhibited the uptake of ${ }^{14} \mathrm{C}$-labelled valine and adenine as well as leucine into the plant cells. This inhibition may be due to various causes, that is, secondary effect of the inhibition of protein synthesis, inhibition of the permiability of cell membrane and so on. Even in our case, the uptake-inhibition may be due to the inhibition of protein synthesis.

Acknowledgement. We express our thanks to Dr. K. Ojima, Tohoku University, for providing us with the suspension cultured cells of soybean and rice plant and for his helpful advice. We also wish to thanks Dr. K. Izaki, Tohoku University, for his helpful advice during this work. 


\section{REFERENCES}

1) K. Tamari and J. Kaji, Nippon Nogeikagaku kaishi, 28, 254 (1954).

2) K. Tamari and J. Kaji, ibid., 33, 178 (1959).

3) K. Tamari and J. Kaji, ibid., 33, 181 (1959).

4) N. Umetsu, J. Kaji and K. Tamari, Agr. Biol. Chem., 36, 859 (1972).

5) S. Iwasaki, H. Muro, S. Okuda and Z. Sato, Tetrahedron Letters, 1, 13 (1972).

6) N. Umetsu, J. Kaji and K. Tamari, Agr. Biol. Chem., 37, 451 (1973).

7) Y. Mikami, N. Nishijima, H. Iimura, A. Suzuki and S. Tamura, ibid., 35, 611 (1971).

8) T. Rosett, R. H. Sankhala, C. E. Stickings, M. E. Talyer and R. Thomas, Biochem. J., 67, 390 (1957)

9) H. T. Shigeura and C. N. Gordon, Biochemistry, 2, 1132 (1963).

10) S. A. Harris, L. V. Fisher and K. Folker, J. Med.
Chem., 8, 478 (1965).

11) Y. Mikami, Y. Nishijima and A. Suzuki, Nippon Nogeikagaku kaishi, 46, 473 (1972).

12) O. L. Gamborg, R. A. Miller and K. Ojima, Exp. Cell Res., 50, 151 (1968).

13) K. Ohira, K. Ojima and A. Fujiwara, Plant Cell Physiol., 14, 1113 (1973).

14) O. H. Lowry, N. J. Rosebrough, A. L. Farr and R. J. Randall, J. Biol. Chem., 193, 265 (1951).

15) C. Schnidt, S. J. Thannhauser, J. Biol. Chem., 161, 83 (1945).

16) D. Vazquez, E. Battaner, R. Neth, G. Heller and R. E. Monro, Cold Spring Harbor Symp. Quant. Biol, , 34, 369 (1969).

17) R. S. Verbin, H. Liang, L. M. Saez, G. Diluiso, P. J. Goldblatt and E. Farber, Exp. Cell Res., 65, 81 (1971).

18) T. A. Rees, and J. A. Bryant, Phytochemistry, 10, 1183 (1971). 